\title{
Intake of nutrients from pasture by pigs
}

\author{
S. A. Edwards \\ Department of Agriculture, University of Newcastle upon Tyne, King George VI Building, \\ Newcastle upon Tyne NE1 7RU, UK
}

\begin{abstract}
The domestic pig evolved from the omnivorous wild boar and has retained many natural foraging behaviour patterns. Although most modern commercial pigs are housed and fed concentrate diets, interest in the potential nutrient contribution from pasture has increased due to growth in outdoor and organic pig production systems. The energy requirements of outdoor pigs are increased by approximately $15 \%$ under Northern European conditions as a result of greater climatic energy demand and locomotory activity. The nutritional contribution made by pasture will depend on the availability, nutrient composition, grazing intake and digestive utilisation of herbage. Information on these topics is currently very sparse. Herbage availability is often low due to farm rotational policy or destructive foraging by the pigs. Herbage composition shows large varietal and seasonal differences, but the high fibre content reduces the efficiency of energy utilisation and may impair utilisation of other nutrients. Intake of grazed herbage varies widely between individuals, but is typically approximately $2.0 \mathrm{~kg} \mathrm{DM} / \mathrm{d}$ for dry sows fed restricted concentrate, and approximately $0 \cdot 1 \mathrm{~kg} \mathrm{DM} / \mathrm{d}$ for growing pigs offered ad libitum concentrate. This intake can contribute $50 \%$ of the maintenance energy requirement and a high proportion of the amino acid, mineral and trace element requirements of dry sows, but $<5 \%$ of requirements of growing pigs. Whilst the potential to increase nutrient intakes from grazing exists, this process requires better understanding of herbage intake and digestion, and development of better systems for paddock management.
\end{abstract}

Pig: Pasture: Foraging behaviour: Nutrient intake

The domestic pig evolved from the wild boar, an omnivore inhabiting forest margins. The size of their home range and extent of winter movements depend on the availability of food. Wild boar and feral pigs, and domestic pigs kept in semi-natural conditions, show similar foraging behaviour, spending $>50 \%$ of their active time in this occupation (Mauget, 1981; Graves, 1984; Stolba \& Wood-Gush, 1989). Foraging behaviour comprises a mixture of grazing and rooting to ingest grasses, fruits, mast crops, roots and invertebrates. Typically, mast crops, nuts and fruits make up the majority of the autumn and winter diet, with grasses, roots, tubers and invertebrates eaten to a greater extent in the summer (Graves, 1984). Feral pigs have also been shown to consume small vertebrates, and eggs, to scavenge on carrion and to predate on small mammals. Foraging typically shows a diurnal pattern, with activity peaks at dawn and dusk, although some populations subjected to hunting become nocturnal (Mauget, 1981). Even under modern commercial outdoor management, with once daily feeding of a concentrate diet meeting nutrient requirements, similar patterns of foraging behaviour are seen. Sows spend $>25 \%$ of the daylight hours engaged in foraging activity, which peaks at dawn and dusk, depending on the time of year (Buckner et al. 1998). Experimental evidence indicates that the domestic pig has retained the ability to show adaptive foraging strategies analogous to those of its wild ancestor (Gustafsson et al. 1999).

Whilst wild and feral pigs must obtain all their energy and nutrient needs by appetitive foraging behaviour, the nutrition of the farmed domestic pig is very different. Only in the case of some traditional systems, such as those used with the Iberian pig grazing oak forest 'dehesa' (Dobao et al. 1988), are domestic pigs of today entirely dependent on foraged food. In autumn foraging these pigs ingest $6-10 \mathrm{~kg}$ acorns and $1-1.5 \mathrm{~kg}$ grass daily, a diet that more than meets their energy requirements, although suboptimal in protein. The majority of pigs are housed without access to pasture and obtain their nutrients from concentrate diets based on cereal and oilseed products. The housing of pigs facilitates management of routine husbandry tasks and, 
more importantly, allows for environmental control to reduce or eliminate the energetic penalty associated with existence at temperatures below the lower critical temperature (Close, 1987). This penalty has major financial consequences, because of poorer feed utilisation in a situation where feed purchase represents more than half the total cost of pigmeat production. When pigs are housed and intensively managed, rate of growth is important to maximise the number of animals utilising expensive housing and labour resources on an annual basis, and thus to reduce overhead costs. In consequence, diets that limit voluntary intake or have poor digestibility as a result of forage ingredients, with a high level of dietary fibre, have not been favoured. This trend has been reinforced by intensive selection of modern genetic lines for carcass lean, which has resulted in a correlated reduction in voluntary food intake in many cases (Webb, 1989).

In recent years, however, there has been renewed interest in keeping pigs outdoors. This interest has resulted from economic pressure to reduce capital cost, diversification of arable farms as world cereal prices fall and opportunities for niche marketing to a sector of the public interested in animal welfare and more natural production systems (Edwards \& Zanella, 1996). In consequence, approximately $30 \%$ of UK sows are maintained outdoors (Sheppard, 1996), although the percentage is lower in other European countries (Edwards, 1994) and outside Europe. The level of outdoor keeping for weaned and growing pigs is much lower, at approximately $11 \%$ of weaned pigs and only $0 \cdot 3 \%$ of growing pigs in the UK (Sheppard, 1996). Even when outdoors these younger animals are often confined in 'hut and run' systems rather than being truly at pasture. The exception to this trend occurs in the case of organic production, where EC Regulation 1804/99 stipulates that all pigs should have outdoor access, and certain UK certification bodies have extended this regulation to include access to pasture. At the present time organic pig production represents $<1 \%$ of the total pig production in the UK, and is no more common in most other countries, but is increasing in response to consumer and retailer demand. The growing number of pigs now kept outdoors has renewed interest in their nutrient requirements under these conditions, and in the contribution that might be made to these requirements by grazing. However, to date, scientific literature on this subject is still relatively scarce.

\section{The nutrient requirements of outdoor pigs}

The nutrient requirements of outdoor pigs have been largely extrapolated from work with housed animals, but this approach is not unreasonable provided that account is taken of the different genetic growth potential of the breeds and selection lines used in these systems. Energy requirements of outdoor pigs are generally higher because of increased climatic energy demand and locomotory activity, whilst protein requirements are relatively unaffected (Close \& Poornan, 1993).

In temperate zones, the major modifications to feed requirements result from exposure to temperatures below the lower critical temperature. The average energy requirement for cold thermogenesis has been proposed to be $15-18 \mathrm{~kJ}$ metabolisable energy/kg metabolic body weight $\left(\mathrm{W}^{0 \cdot 75}\right)$ per $\mathrm{d}$ per $^{\circ}$ below lower critical temperature, although this value can range from as high as $23 \mathrm{~kJ}$ for very thin animals to $7 \mathrm{~kJ}$ for animals in groups (Close \& Poornan, 1993). The problem of cold stress has received most attention in Northern Europe, but in tropical conditions heat stress is likely to be a more important problem for the outdoor pig. Voluntary food intake is reduced as environmental temperature increases. The relationship between temperature and voluntary intake depends on the live weight of the animal (ranging from a $1.0 \%$ decrease in voluntary food intake per ${ }^{\circ}$ at $20 \mathrm{~kg}$ to $2.5 \%$ at $100 \mathrm{~kg}$; Close, 1989) and on its level of metabolic activity. The thermal stress is consequently greatest in the case of the lactating sow, where it has been estimated that for each unit increase in temperature above $16^{\circ}$, voluntary food intake declines by $2.4 \mathrm{MJ}$ digestible energy (Black et al. 1993). Under extremes of environmental temperature, the nature of the dietary energy substrate also becomes relevant for outdoor pigs, since the heat increment of feeding can increase metabolic heat production (Schoenherr et al. 1989). Thus, ingestion of fibre-rich herbages, with high heat increment, will exacerbate heat stress.

In comparison with housed animals, outdoor pigs generally have a large area over which to roam, and a more diverse environment providing greater stimulus for exploratory behaviour. Increased activity can result in a marked increase in the maintenance energy requirement. For confined sows the energy cost of standing has been measured as $14.9 \mathrm{~kJ} / \mathrm{min}$ or $0.26 \mathrm{~kJ} / \mathrm{min}$ per $\mathrm{kg} \mathrm{W}^{0.75}$ (Noblet et al. 1993), close to an earlier estimation of $0.3 \mathrm{~kJ} / \mathrm{min}$ per $\mathrm{kg}$ $\mathrm{W}^{0.75}$ and to estimates for growing pigs of $0 \cdot 26-0 \cdot 30 \mathrm{~kJ} / \mathrm{min}$ per $\mathrm{kg} \mathrm{W}^{0 \cdot 75}$. Surprisingly, the percentage of the day when pregnant sows are active does not appear to be higher in outdoor conditions (10\% for outdoor sows, Buckner, 1996; $18-24 \%$ in different indoor systems, Lambert et al. 1983) and has been shown to depend on their level of hunger. For growing pigs level of activity in outdoor animals has also been reported to be similar to, or lower than, that for animals housed indoors (Guy et al. 1994), and to depend on hunger (Ewbank, 1974). Energy expenditure during activity will be greater if the animal is engaged in locomotion, and depends on the size of animal and the speed of walking. In growing pigs $9.5 \mathrm{~kg}$ animals walking at $4 \mathrm{~km} / \mathrm{h}$ used $23 \mathrm{~kJ} / \mathrm{h}$ per $\mathrm{kg}$ live weight more energy than stationary animals, whereas those walking at $6 \mathrm{~km} / \mathrm{h}$ used $39 \mathrm{~kJ}$ more $(0 \cdot 68-1 \cdot 13 \mathrm{~kJ} / \mathrm{min}$ per $\left.\mathrm{kg} \mathrm{W}^{0.75}\right)$. This finding suggests a requirement of $5 \cdot 8-6 \cdot 3 \mathrm{~kJ} / \mathrm{kg}$ live weight $\left(10 \cdot 1-11 \cdot 3 \mathrm{~kJ} / \mathrm{kg} \mathrm{W} \mathrm{W}^{0 \cdot 75}\right)$ for each $\mathrm{km}$ walked. It should be noted, however, that the heat production of exercised pigs was also greater throughout other times of the day, including the resting period, so that direct measurement during exercise may underestimate the real additional energy requirement of exercised animals. In this experiment the true cost of exercise was twice the energy expended during the exercise bout (Petley \& Bayley, 1988). Estimates of activity cost in outdoor sows are largely speculation, but values of $0.9-3.2 \mathrm{MJ}$ metabolisable energy $/ \mathrm{km}$ walked have been suggested (Close \& Poornan, 1993), based on an expenditure of $7 \mathrm{~kJ} / \mathrm{kg}$ live weight and efficiency of utilisation of $0 \cdot 8$. The way in which the energy requirement for exercise relates to live weight is still largely unknown, although a relationship with $\mathrm{W}^{0 \cdot 75}$ may provide a 
better estimate (Noblet et al. 1993) and would reduce these values. On this basis, a $200 \mathrm{~kg}$ sow walking $1 \mathrm{~km} / \mathrm{d}$ at $4 \mathrm{~km} / \mathrm{h}$ would expend $0.53 \mathrm{MJ}$ metabolisable energy during exercise and $1.2 \mathrm{MJ}$ over the whole day, requiring an extra $1.5 \mathrm{MJ}$ metabolisable energy from food to compensate for this activity. The distance walked by outdoor pigs has not been well quantified. Close (1990) suggested that sows walk between 1 and $10 \mathrm{~km} / \mathrm{d}$, whilst pedometer values measured in one herd indicated a range of $0 \cdot 1-3 \cdot 1 \mathrm{~km} / \mathrm{d}$ (Buckner, 1996). Activity level will depend on many factors including age, stage of the reproductive cycle, climate and nutrition, but there are few good data on this subject. Quantitative distance data for growing pigs are lacking, although time spent in locomotion by outdoor pigs was higher than that for animals in fully-slatted pens, but not for those housed in straw courts (Guy et al. 1994).

The overall effect of these factors on the energy requirement of outdoor pigs is equivalent to an increase in annual feed requirement of approximately $15 \%$ under Northern European conditions (Edwards \& Zanella, 1996).

\section{The contribution of pasture to nutrient requirements}

\section{The availability of feedstuffs}

The extent to which pasture can contribute to the nutrient needs of pigs will depend on herbage type and availability. Herbage is not always available to outdoor pigs; a recent survey of outdoor sow enterprises in the UK indicated that the majority established new paddocks for dry sows or lactating sows on cereal stubble (53 and 46\% respectively), and relatively fewer used established herbage swards (30 and 34\% respectively; HL Edge, HLI Bornett and SA Edwards, unpublished results). Whilst stubble can make a nutrient contribution to foraging pigs through gleaning of shed cereal grains and weed seeds, this contribution has not been quantified and would be expected to be of limited duration. Similarly, where animals are given access to fields with root crops, foraging activity can result in substantial nutrient intakes. Reported levels of intake by dry sows have been as high as $20-30 \mathrm{~kg}$ fresh weight/d for root crops such as potatoes or fodder beet, although only in the case of Chambers et al. (1986) were these levels estimated in the context of pigs foraging on the crop in the ground. Such intakes can more than meet the maintenance requirements of the animal for energy and amino acids.

Even when herbage is initially available in the paddock, the foraging activity of the animals can rapidly remove the herbage, leaving overturned and bare earth for the remainder of the paddock occupation period (Edwards et al. 1998). This below-ground foraging has the potential to yield substantial amounts of nutrients from roots and invertebrates in the short term, although this contribution has not been quantified. However, the rapid depletion of the herbage resource, the damage to landscape and increased risk of nutrient leaching have made such below-ground foraging activity undesirable. To prevent this activity, outdoor sows are commonly fitted with one or more metal rings in the nose to deter rooting. This measure is very effective in maintaining vegetation cover, and thus prolonging possible grazing (Edwards et al. 1998), but does raise serious animal welfare concerns (Horrell et al. 2001). The level of such rooting behaviour appears related to the extent of hunger (Edwards et al. 1993), and hence foraging motivation of the animal. This knowledge has been used in attempts to reduce pasture damage in 'unrung' sows by modifying feeding practice. Increased levels of concentrate feed can reduce foraging behaviour, as can increasing dietary bulk at the same nutrient intake by incorporation of increased levels of dietary fibre (Braund et al. 1998), or offering supplementary forage in the form of silage (Edge et al. 2002) or root crops (HL Edge, CA Bulman and SA Edwards, unpublished results). However, none of these options can entirely abolish rooting, and other strategies to preserve herbage by localising this behaviour to limited areas of the paddock are being investigated (Bornett \& Edwards, 2002).

\section{Nutrient content of herbage}

Where pasture is present, the intake of nutrients by the pig will depend on the voluntary intake and nutritive value of the herbage on offer. There is relatively limited information on the nutrient value of herbage for pigs, and much of these data come from dried forages incorporated into concentrate diets. Herbages generally contain a high proportion of fibre relative to the typical cereal and oilseed constituents of compound pig diets. The effects of increased dietary fibre on the digestive processes are complex and depend on level of fibre in the diet, overall feeding level, live weight and/or age and physiological state (Dierick et al. 1989). Apparent digestibility of fibre in the small intestine is generally low, with the majority of breakdown occurring in the caecum and colon. This factor reflects the key role of fermentation by hindgut microflora in the breakdown of fibre, yielding volatile fatty acids that can, to some extent, be utilised by the pig for energy. However, the energetic efficiency of fermentation in comparison with enzymic digestion and absorption of monosaccharides is substantially less $(0 \cdot 5-0 \cdot 6$ $v .0 \cdot 8)$ as a result of losses associated with production of methane, hydrogen and fermentation heat, and the lower efficiency of utilisation of volatile fatty acids in intermediary metabolism (Noblet \& Le Goff, 2001). Consequently, the net energy:digestible energy values of grazed forages will be lower than those for compound feeds, and comparisons based on apparent digestible energy or metabolisable energy contribution will overestimate forage value.

Fibre sources are not only poorly digested in the small intestine, but can substantially reduce pre-caecal digestibility of other dietary components (Dierick et al. 1989). Various studies have indicated reduced apparent absorption of a number of minerals, including $\mathrm{P}, \mathrm{Ca}, \mathrm{Zn}$ and $\mathrm{Mg}, \mathrm{Cu}$ and $\mathrm{Fe}$. However, this reduction appears to be dependent on the nature of the fibre, and the mechanisms are poorly understood.

A number of estimates of nutritional values of dried herbage species frequently found in pasture used for pigs have been published. An example of the variation between herbages is shown in Table 1. Herbages in these studies were harvested at the budding or early blooming stage, and crude fibre content, whilst not a good representative measure of total fibre content, is given for comparison with Table 2. All herbages showed lower total tract digestibility 
Table 1. The estimated ileal and total tract apparent digestibility of nutrients and gross energy from different dried forages (Andersson \& Lindberg, 1997a, $b$ )

\begin{tabular}{|c|c|c|c|c|}
\hline & $\begin{array}{c}\text { Lucerne } \\
\text { (Medicago sativa) }\end{array}$ & $\begin{array}{c}\text { White clover } \\
\text { (Trifolium repens) }\end{array}$ & $\begin{array}{c}\text { Red clover } \\
\text { (Trifolium pratense) }\end{array}$ & $\begin{array}{c}\text { Ryegrass } \\
\text { (Lolium spp.) }\end{array}$ \\
\hline \multicolumn{5}{|l|}{ Composition (g/kg DM) } \\
\hline Crude fibre & 341 & 163 & 195 & 236 \\
\hline Total fibre & 708 & 610 & 638 & 677 \\
\hline Sugar & 6 & 24 & 13 & 29 \\
\hline Crude protein $(\mathrm{N} \times 6 \cdot 25)$ & 174 & 241 & 215 & 152 \\
\hline \multicolumn{5}{|l|}{ Ileal digestibility } \\
\hline Organic matter & $0 \cdot 12$ & $0 \cdot 13$ & $0 \cdot 10$ & -0.02 \\
\hline Crude protein & 0.52 & 0.56 & 0.43 & 0.09 \\
\hline Energy & $0 \cdot 10$ & $0 \cdot 13$ & -0.01 & $-0 \cdot 20$ \\
\hline \multicolumn{5}{|l|}{ Total tract digestibility } \\
\hline Organic matter & $0 \cdot 40$ & 0.50 & 0.42 & 0.22 \\
\hline Crude protein & 0.49 & 0.52 & $0 \cdot 38$ & 0.08 \\
\hline Energy & 0.35 & 0.45 & $0 \cdot 31$ & 0.04 \\
\hline
\end{tabular}

Table 2. The composition of dried grass meal from different seasonal cuts of a ryegrass (Lolium spp.)-red clover (Trifolium pratense) pasture and its apparent digestibility in growing pigs and sows (Vestergaard et al. 1995)

\begin{tabular}{|c|c|c|c|c|}
\hline & Cut 1 & Cut 2 & Cut 3 & SE \\
\hline \multicolumn{5}{|c|}{$\begin{array}{l}\text { Composition of grassmeal } \\
(\mathrm{g} / \mathrm{kg} \text { DM })\end{array}$} \\
\hline Crude fibre & 231 & 275 & 286 & \\
\hline Cellulose & 165 & 208 & 212 & \\
\hline Sugar & 141 & 99 & 57 & \\
\hline \multicolumn{5}{|c|}{ DM apparent digestibility (\%) } \\
\hline Growing pigs & 58 & 45 & 40 & 3 \\
\hline Sows & 62 & 53 & 50 & 3 \\
\hline \multicolumn{5}{|c|}{$\begin{array}{l}\text { Crude protein }(\mathrm{N} \times 6 \cdot 25) \\
\quad \text { apparent digestibility }(\%)\end{array}$} \\
\hline Growing pigs & 13 & 17 & 11 & 6 \\
\hline Sows & 39 & 39 & 36 & 5 \\
\hline \multicolumn{5}{|c|}{$\begin{array}{l}\text { Metabolisable energy } \\
(\mathrm{MJ} / \mathrm{kg} \mathrm{DM})\end{array}$} \\
\hline Growing pigs & $9 \cdot 6$ & $7 \cdot 4$ & $6 \cdot 3$ & 0.6 \\
\hline Sows & $10 \cdot 1$ & $8 \cdot 8$ & $8 \cdot 3$ & $0 \cdot 6$ \\
\hline
\end{tabular}

of protein and energy than barley, and approximately $60 \%$ of their apparent energy digestibility occurred in the hindgut, indicating a predominance of fermentation rather than enzymic digestion. Digestibility of ryegrass was poor in comparison with that of legume species.

The nutritional value of a herbage is strongly influenced by its stage of maturity. For example, dried grass meal derived from the first (31 May), second (7 July) and third (26 August) annual cut from the same ryegrass (Lolium spp.)-red clover (Trifolium pratense) pasture showed reduced sugar content, increased content of dietary fibre and decreased apparent digestibility (Table 2; Vestergaard et al. 1995). Digestibility measurements were investigated separately for growing pigs (40-60 kg live weight) and adult sows (approximately $200 \mathrm{~kg}$ live weight). Both groups showed a similar decline in digestibility across samples, but sows showed a consistently higher herbage digestibility than growing pigs that was attributable to higher digestibility of the fibre fraction. The greater gut capacity and slower rate of passage in adult sows increases their ability to obtain nutrients from fibrous feeds as a result of hindgut fermentation, and hence makes them better equipped to utilise herbages.

There have been a few studies of digestibility using fresh cut forage. Apparent digestibility of DM of autumn fresh ryegrass by sows was measured at 0.58 (Stephen, 1976). In growing pigs (40-70 kg live weight) the digestibility of DM in the total diet was reduced with high herbage intakes (12-15\% DM intake), but not with lower herbage intakes (6-9\% DM intake) from a grass-clover mix $(\mathrm{g} / \mathrm{kg} ; 130 \mathrm{DM}$, 199 crude protein $(\mathrm{N} \times 6.25), 106$ sugars, 457 total fibre;Carlson et al. 1998). More detailed results for apparent faecal digestibilities are presented by Carlson et al. (1999) for a slightly better quality grass-clover mix $(\mathrm{g} / \mathrm{kg} ; 190 \mathrm{DM}$, 241 crude protein, 347 total fibre) at a herbage intake of $1.137 \mathrm{~kg}$ fresh weight $/ \mathrm{d}$ (19\% total DM intake). The results showed apparent diet (concentrate + herbage) digestibilities of 0.81 for gross energy, 0.83 for crude protein. The organic matter digestibility of 0.81 was slightly higher than that predicted in vitro $(0 \cdot 80)$. Estimates for the herbage itself were obtained only from in vitro measurements and gave an organic matter digestibility of $0 \cdot 64$. The estimated energy contribution of this type of herbage mix was $0 \cdot 12$ Danish feed units $/ \mathrm{kg}(1.6 \mathrm{MJ}$ digestible energy $/ \mathrm{kg}$ fresh weight or $5.5 \mathrm{MJ}$ net energy/kg DM; Danielsen et al. 1999).

Studies of digestibility of forages under grazing conditions are limited. The organic matter digestibility of herbage grazed from a ryegrass-white clover (Trifolium repens) sward by dry sows has been estimated using the alkane marker technique (Rivera Ferre et al. 2001). The value varied from 0.8 to 0.5 at different times of the year (Table 3 ), giving estimated digestible energy values for fresh herbage of $2.9 \mathrm{MJ} / \mathrm{kg}$ in spring and $1.9 \mathrm{MJ} / \mathrm{kg}$ in summer $(12.7$ and $7 \cdot 3 \mathrm{MJ} / \mathrm{kg}$ DM respectively). A limited study with growing pigs using the same technique indicated an organic matter 
Table 3. The digestibility and voluntary intake of herbage from a ryegrass (Lolium spp.)-clover (Trifolium repens) sward by grazing sows in different seasons (Rivera Ferre et al. 2001)

\begin{tabular}{llll}
\hline & Spring & Summer & SE \\
\hline Herbage composition & & & \\
DM $(\mathrm{g} / \mathrm{kg})$ & 229 & 260 & \\
NDF (g/kg OM) & 457 & 525 & \\
Apparent digestibility of OM & 0.79 & 0.47 & 0.04 \\
Herbage intake (kg/d) & & & \\
Fresh weight & 5.8 & 7.3 & 0.7 \\
OM & 1.1 & 1.5 & 0.2 \\
\hline
\end{tabular}

NDF, neutral-detergent fibre; OM, organic matter.

digestibility of grazed herbage of $0 \cdot 84$, at a low herbage intake level from a spring ryegrass-white clover sward (Mowat et al. 2001). Given a standard concentrate diet of 12.5-13.0 MJ digestible energy, these values suggest a substitution rate of fresh grass for concentrate feed of approximately $4: 1$ and $7: 1$ in spring and summer. It is of interest, therefore, to note that nutrition textbooks written at the time when traditional outdoor sow keeping was common (for example, see Ellis, 1937) and early experiments involving use of grass for sows (Boaz, 1962; Nappan Experimental Farm, 1964) suggest a substitution rate of grass for concentrate of 7:1. A similar value is indicated by more recent Danish studies with mixed grass-clover herbage for finishing pigs (Danielsen et al. 1999), but a poorer substitution rate $(9: 1$ or $10: 1)$ was suggested for younger growing pigs (Davidson, 1930). It must always be borne in mind, however, that the nutrient value will depend on the species mix, season and extent of plant selection shown by the pig, and that data on these aspects are very limited.

\section{Herbage intake}

Data are equally scarce on the intake of grazed herbage by pigs. The mean intakes of dry sows measured by Rivera Ferre et al. (2001) are shown in Table 3. These values are in accord with that of $1.2 \mathrm{~kg} \mathrm{DM} / \mathrm{d}$ (approximately $7.5 \mathrm{~kg}$ fresh weight/d) for cut fresh autumn ryegrass measured by Stephen (1976), and $6.3 \mathrm{~kg}$ fresh grass/d reported from earlier studies (Crowther, 1934; Boaz, 1962). However, slightly higher intakes of $2.4 \mathrm{~kg} \mathrm{DM} / \mathrm{d}$ in early summer and $3.7 \mathrm{~kg} \mathrm{DM} / \mathrm{d}$ in late summer were measured by Sehested et al. (1999), and much higher estimates of $11.5 \mathrm{~kg}$ fresh herbage/d were obtained by Gannon (1996) for dry sows grazing spring herbage. The studies of both Rivera Ferre et al. (2001) and Gannon (1996) suggested that these intakes were not greatly influenced by the level of supplementary concentrate (within the typical commercial range for dry sows). However, individual variation in herbage intake was very high, ranging between $1 \cdot 1$ and $10.5 \mathrm{~kg}$ fresh weight/d in spring and 4.3 and $11.8 \mathrm{~kg}$ in summer.

Data on herbage intake of growing pigs are even more scarce. A limited study with growing pigs $(50-60 \mathrm{~kg}$ live weight) using the n-alkane marker technique indicated a mean daily intake of $0.10 \mathrm{~kg}$ organic matter $/ \mathrm{d}(0.5 \mathrm{~kg}$ fresh weight/d) by growing pigs from a spring ryegrass-white clover sward when also offered ad libitum concentrate
(Mowat et al. 2001). Once again, individual variation was high, with a range of $0 \cdot 07-0 \cdot 16 \mathrm{~kg}$ organic matter/d. Carlson et al. (1999) measured intake of cut grass-clover herbage by growing pigs (40-70 kg live weight) and recorded values of $830-2298 \mathrm{~g}$ fresh weight $(0 \cdot 16-0 \cdot 44 \mathrm{~kg} \mathrm{DM}) / \mathrm{d}$, making up $6-15 \%$ of the daily DM intake.

Riart (2002) estimated herbage intakes of growing pigs from 30 to $100 \mathrm{~kg}$ live weight when rotationally grazed on a series of paddocks composed of lucerne (Medicago sativa), fescue (Festuca arundinacea) and Cebadilla criolla. The pigs were offered concentrate with a sub-optimal protein content ad libitum and herbage intakes were measured by pasture sampling before and after paddock occupation. Mean intakes of herbage by growing pigs (30-70 kg live weight) were $0 \cdot 15 \mathrm{~kg} \mathrm{DM} / \mathrm{d}$ in spring and $0.04 \mathrm{~kg} \mathrm{DM} / \mathrm{d}$ in summer, whilst those of finishing pigs $\quad(70-100 \mathrm{~kg}$ live weight) were 0.51 and $0.32 \mathrm{~kg} \mathrm{DM} / \mathrm{d}$ respectively.

Intake of herbage by growing pigs depends heavily on the level of supplementary concentrate feeding provided. In a study with cut grass-clover herbage, growing pigs (27 to $100 \mathrm{~kg}$ live weight) given a low level of supplementary concentrate $(70 \%$ of normal allowance) consumed $1 \cdot 1 \mathrm{~kg}$ fresh herbage $/ \mathrm{d}$ (approximately $0.2 \mathrm{~kg} \mathrm{DM} / \mathrm{d}$ or $5 \%$ of the daily energy intake), which was $32 \%$ more than that of pigs given the normal (semi ad libitum) allowance of supplementary concentrate $(0.8 \mathrm{~kg}$ fresh herbage $/ \mathrm{d}, 0 \cdot 15 \mathrm{~kg} \mathrm{DM} / \mathrm{d}$ or $4 \%$ of the daily energy intake; Danielsen et al. 1999). This increase in herbage intake was inadequate to maintain live-weight gain, which was reduced by $11 \%$. It is well established that the ability of pigs to increase intake in response to reduced dietary nutrient concentration is limited, probably by the capacity of gastrointestinal tract, and increases with the age and/or weight of the pig. This constrained food intake $(\mathrm{kg} / \mathrm{d})$ has been estimated by Black et al. (1986) to be $0 \cdot 111 \mathrm{~W}^{0 \cdot 803}$. However, this approach is still an oversimplification, since it is known that feeds with different water-holding capacities, as a consequence of different dietary NSP composition, exert different effects on intake capacity (Tsaras et al. 1998). The characterisation of constrained voluntary intake of grazed herbages in relation to live weight has yet to be defined.

The extent to which pigs differentially select plants of different species, or different parts of the same plant, when offered a mixed sward is also largely unstudied. In the only quantitative study of individual grazing intake (Mowat et al. 2001), only one of six animals showed evidence of selective grazing of the clover component of a ryegrass-white clover sward. However, Carlson et al. (1999) recorded selective consumption of high-sugar components from a cut grassclover mix by growing pigs. Observations of change in sward composition have also suggested preferential grazing of clover from a grass-clover sward (Sehested et al. 1999), and of lucerne from a lucerne-grass sward (Riart, 2002).

\section{Contribution of herbage to nutrient requirements}

The net contribution of grazed pasture to the nutrient intake of pigs can therefore be estimated from the studies reported earlier, and from other studies in which production measures (generally change in live-weight gain) have been measured for comparable groups of pigs with and without pasture 
access. Studies on the dry sow indicate that, when an adequate supply of herbage is present, it can contribute approximately $50 \%$ of the maintenance energy requirement of the animal during spring and summer (Rivera Ferre et al. 2001). This level of contribution was achieved to an extent by compensation in intake for reduced herbage quality, such that digestible energy intakes of 16-18 MJ/d were recorded in both seasons. However, individual sow variation was great, with a range of $12-92 \%$ maintenance requirement in spring and $2-77 \%$ maintenance requirement in summer. Sehested et al. (1999) estimated the contribution of pasture to be equivalent to 1 Danish feed unit/d (12.9 MJ digestible energy). However, herbage is not necessarily available throughout the year and the period of high nutrient quality is very limited. It is of interest to note that sows maintained over a long period of time on paddocks with relatively plentiful or scarce herbage, as a consequence of being grazed by sows with or without nose-rings, showed no significant difference in gain of live weight or backfat thickness (Edwards et al. 1998).

In the case of growing pigs, intake from a grass-clover sward contributed only $4 \%$ of the daily organic matter intake when concentrate was available ad libitum (Mowat et al. 2001). The contribution made by pasture clearly depends on the season and the live weight of the pig. Riart (2002) estimated that the percentage contribution of pasture to the total DM intake of growing and finishing pigs was 7 and 15 respectively in spring and 2 and 10 in summer. When compared with pigs fed the same sub-optimal-protein diet, but maintained in paddocks without herbage, live-weight gain of growing pigs (30-70 kg live weight) was not significantly increased in either spring or summer, although concentrate intake per $\mathrm{kg}$ live-weight gain was reduced by $4 \%$. Calculations based on pig performance suggested that the percentage of protein requirements obtained from pasture was 6 in spring and $0 \cdot 2$ in summer. In finishing pigs (70-100 kg live weight) a tendency towards an interaction between pasture availability and season was seen in performance, with spring pigs showing improved growth and summer pigs showing reduced growth rate when pasture was on offer. This variation was reflected in the concentrate intake per kg live-weight gain, which was improved by $19 \%$ in spring but only $5 \%$ in summer, and the calculated contribution to protein requirements of 18 and $2 \%$ respectively. This summer reduction was attributable to an increase in the fibre content of the herbage, and to a reduced percentage of legume in the pasture, with a recorded decline in DM content from 220 to $90 \mathrm{~g} / \mathrm{kg}$ as the season progressed.

Grazed legume pastures have the potential to make an important contribution to the amino acid requirements of pigs, with reported lysine concentrations of approximately $7 \mathrm{~g} / \mathrm{kg}$ DM in grass and $9 \mathrm{~g} / \mathrm{kg} \mathrm{DM}$ in lucerne (Ewing, 1997; Frame et al. 1998). However, there have been relatively few studies of the ileal digestibility of amino acids from fresh herbage. Most information has been derived from the study of dried herbages (see Table 1) and it indicates an apparent ileal digestibility in the range of $0.4-0.5$ (Andersson \& Lindberg, 1997a, $b$; Lindberg \& Cortova, 1995). The amino acid content and digestibility will depend on the species and stage of growth of the herbage; values will be higher for legumes than for grasses, but currently information is sparse. However, the major influence on the contribution of pasture to amino acid requirements will be the level of grazing intake. Thus, it can be estimated that the potential contribution of grazed legume pasture to amino acid requirements of the pregnant sow is substantial, whereas the growing pig fed concentrate ad libitum will obtain a negligible contribution (Fig. 1).

In addition to the contribution to energy and protein requirements, herbage has the potential to make an important contribution to mineral, trace element and vitamin supply. This aspect has not been addressed in the pig to date, but will assume increasing importance in organic production systems where artificial supplementation is constrained. The

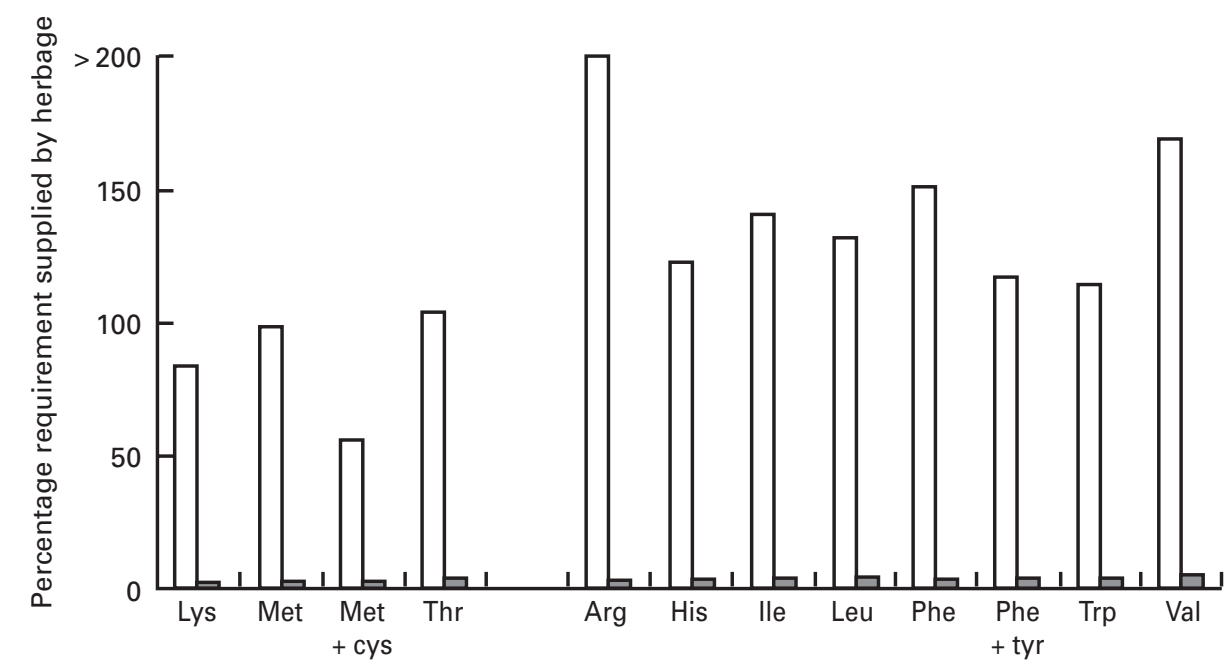

Fig. 1. The potential contribution of a grazed grass-clover sward to the amino acid requirements of pigs. Requirements are based on National Research Council (1998) and the contribution of herbage on an assumed ileal digestibility of $0 \cdot 4$, an assumed intake of $2 \mathrm{~kg} \mathrm{DM} / \mathrm{d}$ for dry sows ( $\square$ ) and $0.1 \mathrm{~kg} \mathrm{DM} / \mathrm{d}$ for growing pigs $(50-80 \mathrm{~kg}$ live weight; $\square$ ) offered ad libitum concentrate (for details, see p. 262). 
mineral content of herbage will depend on the species, stage of maturity, soil characteristics and fertilising regimen. Leguminous species generally have higher mineral and trace element contents than grasses (Underwood \& Suttle, 1999). Information on the availability of herbage minerals is lacking, but may be influenced by the concentration and type of fibre present in the plant (see previous discussion). As is the case for amino acids, the potential contribution of grazed legume pasture to requirements of the pregnant sow is substantial, whereas the growing pig fed concentrate ad libitum will obtain a negligible contribution (Fig. 2). Herbage is also rich in vitamins A and E, and many of the B vitamins, especially riboflavin. Theoretically, at the levels of intake reviewed previously all requirements for vitamins $\mathrm{A}$ and $\mathrm{E}$ and riboflavin of the dry sow could be supplied from grazing, and $30-50 \%$ of the requirements of the growing pig.

\section{Nutrient intakes from soil}

Even where herbage is not present it is possible that pigs may ingest substantial levels of micronutrients from the soil, particularly when animals are not fitted with nose rings and substantial rooting can occur. Estimates of soil ingestion by foraging pigs are lacking. However, in one study of sows faecal ash content, largely indicative of soil ingestion, varied from 19 to $94 \%$ (Rivera Ferre et al. 2001). The metabolic contribution of soil ingestion has not been studied, since most animals receive conventional supplements that oversupply requirements. However, one circumstance in which a contribution from pasture to micronutrient require- ments has been documented is that of Fe for the suckling piglet. It has been demonstrated that whereas indoor piglets require administration of supplementary $\mathrm{Fe}$ to prevent anaemia during the first weeks of life, outdoor piglets do not show this requirement, although this situation may be influenced by the soil Fe content (Brown et al. 1996). The potential for energy and nutrient intakes from soil fauna should also not be ignored. Invertebrates are readily eaten by pigs and have a substantial nutrient content (Bassler et al. 1999). In one study the recorded intake of earthworms by village pigs (20-40 kg live weight) ranged from 414 to 1224 worms per d, providing on average a daily intake of $29.3 \mathrm{~g}$ protein and $1.8 \mathrm{~g}$ lysine (Rose \& Williams, 1983).

\section{Conclusion}

Ingestion of herbage and soil by pigs at pasture can make a substantial contribution to the energy, amino acid, mineral and micronutrient requirements of the dry sow, where foraging motivation is high as a consequence of restricted concentrate feeding and the capacity for intake and hindgut fermentation of bulky feeds is great. However, this situation does not pertain in the growing pig where, under modern commercial circumstances of feeding concentrate ad libitum, $<5 \%$ of nutrient requirements are met from herbage. Whilst herbage contribution can be increased if supplementary concentrate is reduced, there will be an associated penalty in animal performance. The potential to increase nutrient intakes from pasture exists, but requires a better understanding of nutrient utilisation, voluntary intake and diet selection of different plant species under grazed conditions,

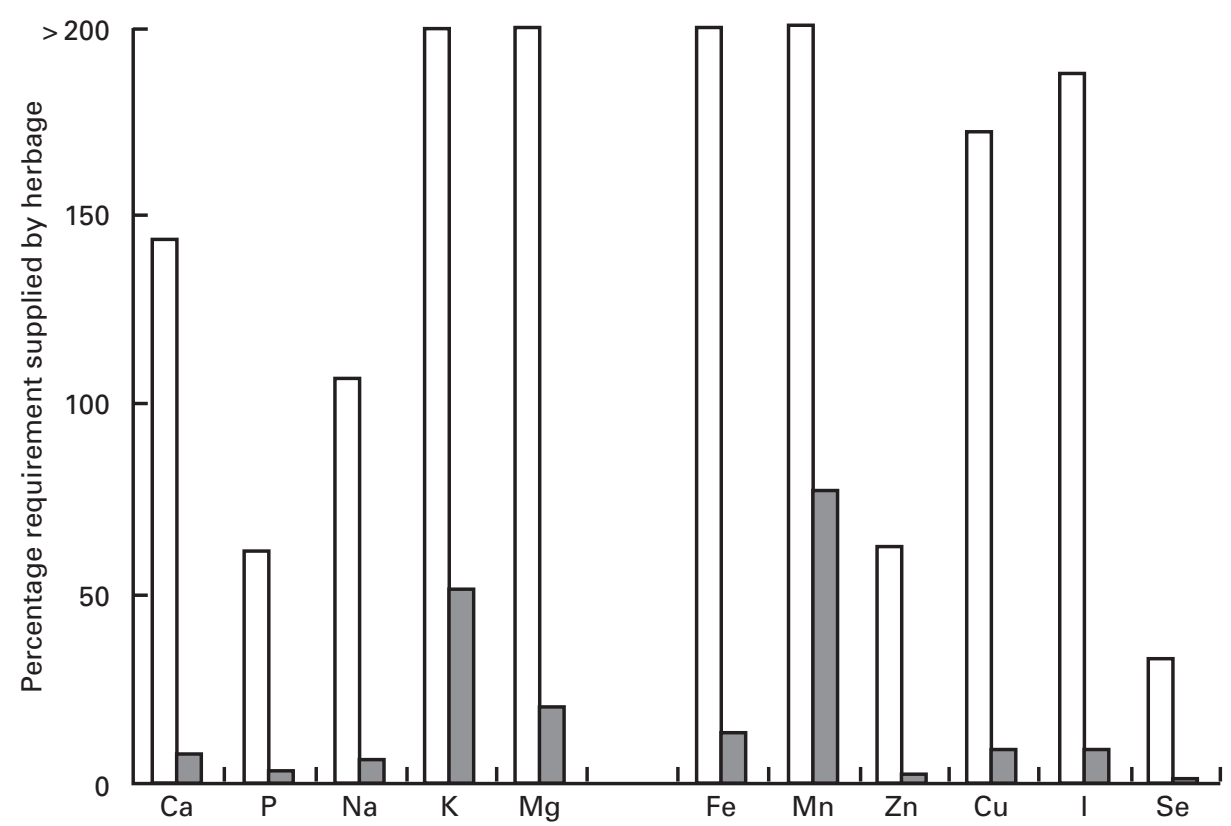

Fig. 2. The potential contribution of a grazed grass-clover sward to the mineral and trace element requirements of pigs. Requirements are based on National Research Council (1998) and the contribution of herbage on an assumed intake of $2 \mathrm{~kg} \mathrm{DM} / \mathrm{d}$ for dry sows ( $\square$ ) and $0.1 \mathrm{~kg} \mathrm{DM} / \mathrm{d}$ for growing pigs (50-80 kg live weight; $\square$ ) offered ad libitum concentrate (for details, see p. 262). No allowance for availability is made in these estimates. 
and the development of better systems for paddock management that permit utilisation of herbage without serious sward destruction.

\section{References}

Andersson C \& Lindberg JE (1997a) Forages in diets for growing pigs. 1. Nutrient apparent digestibilities and partition of nutrient digestion in barley-based diets including lucerne and whiteclover meal. Animal Science 65, 483-491.

Andersson C \& Lindberg JE (1997b) Forages in diets for growing pigs. 2. Nutrient apparent digestibilities and partition of nutrient digestion in barley-based diets including red clover and perennial ryegrass meal. Animal Science 65, 493-500.

Bassler A, Ciszuk P \& Sjelin K (1999) Management of laying hens in mobile houses - a review of experiences. In Ecological Animal Husbandry in the Nordic Countries, pp. 45-50 [JE Hermansen, $\mathrm{V}$ Lund and E Thuen, editors]. Foulum, Denmark: Danish Research Centre for Organic Farming.

Black JL, Campbell RG, Williams IH, James KJ \& Davies GT (1986) Simulation of energy and amino acid utilisation in the pig. Research and Development in Agriculture 3, 121-145.

Black JL, Mullan BP, Lorschy ML \& Giles LR (1993) Lactation in the sow during heat stress. Livestock Production Science 35, $153-170$.

Boaz TG (1962) The significance of level of protein in the nutrition of the pregnant sow. Veterinary Record 74, 1482-1489.

Bornett HLI \& Edwards SA (2002) Alternatives to nose ringing in outdoor sows: the provision of a special rooting area. Proceedings of the British Society of Animal Science, p. 38. Penicuik, Lothian: British Society of Animal Science.

Braund JP, Edwards SA, Riddoch I \& Buckner LJ (1998) Modification of foraging behaviour and pasture damage by dietary manipulation in outdoor sows. Applied Animal Behaviour Science 56, 173-186.

Brown JME, Edwards SA, Smith WJ, Thompson E \& Duncan J (1996) Welfare and production implications of teeth clipping and iron injection of piglets in outdoor systems in Scotland. Preventive Veterinary Medicine 27, 95-105.

Buckner LJ (1996) Physical and mathematical modelling of the energy requirements of the outdoor sow. $\mathrm{PhD}$ Thesis, University of Aberdeen.

Buckner LJ, Edwards SA \& Bruce JM (1998) Behaviour and shelter use by outdoor sows. Applied Animal Behaviour Science 57, 69-80.

Carlson D, Johansen HN, Poulsen HD \& Jorgensen H (1998) Fordoejelighed og udnyttelse af grovfoder til slagtesvin (Digestibility and utilisation of roughage for growing pigs). In Forskning i Oekologisk Svineproduktion (Research in Ecological Pig Production), pp. 13-17 [J Hermansen, editor]. Foulum, Denmark: Danmarks Jordbrugsforskning.

Carlson D, Laerke HN, Poulsen HD \& Jorgensen H (1999) Roughages for growing pigs, with emphasis on chemical composition, ingestion and faecal digestibility. Acta Agriculturae Scandinavica 49A, 129-136.

Chambers J, Hardy B \& Pugh O (1986) The use of an electronically controlled sow feeder to supply a compound feed as a balancer to sows grazing fodder beet. Proceedings of the British Society of Animal Science, paper no. 121. Penicuik, Lothian: British Society of Animal Production.

Close WH (1987) The influence of the thermal environment on the productivity of pigs. In Pig Housing and the Environment. Occasional Publication of the British Society of Animal Production no. 11, pp. 9-24 [AT Smith and TLJ Lawrence, editors]. Edinburgh: British Society of Animal Production.
Close WH (1989) The influence of the thermal environment on the voluntary food intake of pigs. In The Voluntary Food Intake of Pigs. Occasional Publication of the British Society of Animal Production no. 13, pp. 87-96 [JM Forbes, MA Varley and TLJ Lawrence, editors]. Edinburgh: British Society of Animal Production.

Close WH (1990) Nutrition of outdoor pigs. In Outdoor Pigs, pp. 61-84 [BA Stark, DH Machin and JM Wilkinson, editors]. Marlow, Bucks.: Chalcombe Publications.

Close WH \& Poornan PK (1993) Outdoor pigs - their nutrient requirements, appetite and environmental responses. In Recent Advances in Animal Nutrition, pp. 175-196 [W Haresign and DJA Cole, editors]. Nottingham: Nottingham University Press.

Crowther C (1934) Pig Breeding Annual no. 14.

Danielsen V, Lydehoj Hansen L, Moller F, Bejerholm C \& Nielsen $S$ (1999) Production results and sensory meat quality of pigs fed different amounts of concentrate and ad lib. Clover grass or clover grass silage. In Ecological Animal Husbandry in the Nordic Countries pp. 79-86 [JE Hermansen, V Lund and E Thuen editors]. Foulum, Denmark: Danish Research Centre for Organic Farming.

Davidson HR (1930) The value of grazing for fattening pigs. Scottish Journal of Agriculture XIII, 3.

Dierick NA, Vervaeke IJ, Demeyer DI \& Decuypere JA (1989) Approach to the energetic importance of fibre digestion in pigs. 1. Importance of fermentation in the overall energy supply. Animal Feed Science and Technology 23, 141-167.

Dobao MT, Rodriganez J, Silio L \& Toro MA (1988) Iberian pig production in Spain. Pig News and Information 9, 277-282.

Edge HL, Bornett H, Newton EJ \& Edwards SA (2002) Overground enrichment-a possible alternative to nose ringing in outdoor pigs? Proceedings of the 36th International Congress of the International Society for Applied Ethology, Egmond aan Zee (In the Press).

Edwards SA (1994) Outdoor pig production: the European perspective. Pig News and Information 15, 111N-112N.

Edwards SA, Atkinson KA \& Lawrence AB (1993) The effect of food level and type on behaviour of outdoor sows. Proceedings of the 3rd Joint Meeting of the International Congress on Applied Ethology, pp. 501-503 [M Nichelmann, HK Wierenga and S Braun editors]. Berlin: Humboldt University Press.

Edwards SA, Jamieson W, Riddoch I \& Watson CA (1998) Effect of nose ringing and dietary modification in outdoor pig production on temporal changes in soil nitrogen status. Proceedings of the British Society of Animal Science, p. 42. Penicuik, Lothian: British Society of Animal Science.

Edwards SA \& Zanella A (1996) Producao de suinos ao ar livre na Europa: bem-estar e consideracoes ambientais. [Pig production in outdoor systems in Europe: production, welfare and environmental considerations]. A Hora Veterinara 92, 86-93.

Ellis JCB (1937) The Feeding of Farm Livestock. London: Crosby Lockwood and Son.

Ewbank R (1974) The influence of diet on general activity in fattening pigs. Proceedings of the International Pig Veterinary Society, Lyons 3, 64.

Ewing WN (1997) The Feeds Directory. Heather, Leics.: Context Publications.

Frame J, Charlton JFL \& Laidlaw AS (1998) Temperate Forage Legumes. Wallingford, Oxon: CAB International.

Gannon MA (1996) The energy balance of pigs outdoors. PhD Thesis, University of Nottingham.

Graves HB (1984) Behaviour and ecology of wild and feral swine (Sus scrofa). Journal of Animal Science 58, 482-492.

Gustafsson M, Jensen P, de Jong FH \& Schuurman T (1999) Domestication effects on foraging strategies in pigs (Sus scrofa). Applied Animal Behaviour Science 62, 305-317. 
Guy JH, Chadwick JP \& Rowlinson P (1994) The effect of housing system on the welfare and productivity of two genotypes of finishing pigs. Pig News and Information 15, 131N-133N.

Horrell RI, A'Ness PJA, Edwards SA \& Eddison J (2001) The use of nose rings in pigs: consequences for rooting, other functional activities and welfare. Animal Welfare 10, 3-22.

Lambert RJ, Ellis M, Rowlinson P \& Saville CA (1983) Influence of housing/feeding system on sow behaviour. Animal Production 36, 532 .

Lindberg JE \& Cortova Z (1995) The effect of increasing inclusion of lucerne leaf meal in a barley-based diet on the partition of digestion and on nutrient utilisation in pigs. Animal Feed Science Technology 56, 11-20.

Mauget R (1981) Behavioural and reproductive strategies in wild forms of Sus scrofa (European wild boar and feral pigs). In The Welfare of Pigs, pp. 3-13 [W Sybesma, editor]. The Hague: Martinus Nijhoff.

Mowat D, Watson CA, Mayes RW, Kelly H, Browning H \& Edwards SA (2001) Herbage intake of growing pigs in an outdoor organic production system. Proceedings of the British Society of Animal Science, p. 169. Penicuik, Lothian: British Society of Animal Science.

Nappan Experimental Farm (1964) Sows Fed with Grass. Nappan, NS: Department of Agriculture.

National Research Council (1998) Nutrient Requirements of Swine. Washington, DC: National Academy Press.

Noblet J \& Le Goff G (2001) Effect of dietary fibre on the energy value of feeds for pigs. Animal Feed Science and Technology $\mathbf{9 0}$, $35-52$.

Noblet J, Shi XS \& Dubois S (1993) Energy cost of standing activity in sows. Livestock Production Science 34, 127-136.

Petley MP \& Bayley HS (1988) Exercise and post exercise energy expenditure in growing pigs. Canadian Journal of Physiology and Pharmacology 66, 721-730.

Riart GR (2002) Some aspects of outdoor pig production in Argentina. PhD Thesis, University of Aberdeen.

Rivera Ferre MG, Edwards SA, Mayes RW, Riddoch I \& Hovell FdeB (2001) The effects of season and level of concentrate on the voluntary intake and digestibility of herbage by outdoor sows. Animal Science 72, 501-510.

Rose CJ \& Williams WT (1983) Ingestion of earthworms, Pontoscolex corethrurus, by village pigs, Sus scrofa papuensis, in the highlands of Papua New Guinea. Applied Animal Ethology 11, 131-139.

Schoenherr WD, Stahley TS \& Cromwell GL (1989) The effects of dietary fat or fibre addition on yield and composition of milk from sows housed in a warm or hot environment. Journal of Animal Science 67, 482-495.

Sehested J, Soegaard K, Danielsen V \& Kristensen VF (1999) Mixed grazing with sows and heifers: effects on animal performance and pasture. In Ecological Animal Husbandry in the Nordic Countries, pp. 35-39 [JE Hermansen, V Lund and E Thuen editors]. Foulum, Denmark: Danish Research Centre for Organic Farming.

Sheppard A (1996) The Structure of Pig Production in England and Wales. Special Studies in Agricultural Economics, Report no. 33, Exeter, Devon: University of Exeter.

Stephen TG (1976) A preliminary evaluation of the value of grass and grass pulp to non-lactating sows. MSc Thesis, University of Aberdeen.

Stolba A \& Wood-Gush DGM (1989) The behaviour of pigs in a semi-natural environment. Animal Production 48, 419-425.

Tsaras LN, Kyriazakis I \& Emmans GC (1998) The prediction of the voluntary food intake of pigs on poor quality foods. Animal Science 66, 713-723.

Underwood EJ \& Suttle NF (1999) The Mineral Nutrition of Livestock. Wallingford, Oxon.: CABI International.

Vestergaard E-M, Danielsen V \& Larsen AE (1995) Utilisation of dried grass meal by young growing pigs and sows. Proceedings of the 45th Annual Meeting of the European Association for Animal Production, Prague, paper N2b. Wageningen, The Netherlands: Wageningen Pers.

Webb AJ (1989) Genetics of food intake in the pig. In The Voluntary Food Intake of Pigs. Occasional Publication of the British Society of Animal Production no. 13, pp. 41-50 [JM Forbes, MA Varley and TLJ Lawrence editors]. Edinburgh: British Society of Animal Production. 